\title{
Shorelines and Rising Sea Levels in Eastern Canada
}

\section{by Donald L. Forbes, Robert B. Taylor, and John Shaw}

One of the major impacts of a climate warming is likely to be a rise in sea level. Many studies are now concentrating on coastal regions in order to determine the effects, past and present, of changes in sea level on shorelines and on the people who live nearby. This article and the following one by John Clague summarize respectively recent work along Canada's low-lying eastern coast and its more rugged western one, which provides part of the scientific background required in order to understand and cope with changes in the coastal zone. The authors show here the importance of variations, not only in sea level, but also in conditions of sediment supply. (Ed.)

\section{The Background}

Coastal erosion can be a serious concern for those who settle or build near the ocean or along the shores of large lakes. It is an issue in many areas of the Canadian Atlantic Provinces (Fig. 1), where local mean (relative) sea levels are rising and coastal sediment supplies are limited. In some places erosion proceeds slowly, presenting little threat to coastal property and resulting in spectacular scenery with real, if intangible, economic value as a tourist attraction (Fig. 2). In other areas, erosion proceeds more rapidly, resulting in the destruction of valuable property (Eyles et al., 1985), the disappearance or radical modification of beaches (Bowen et al., 1975; Taylor et al., 1985; Boyd et al., 1987), the failure of engineering works (Reinson and Frobel, 1980; Readshaw, 1987), or the cutting of roads and other services. The end of the road to Rustico (Fig. 3) illustrates

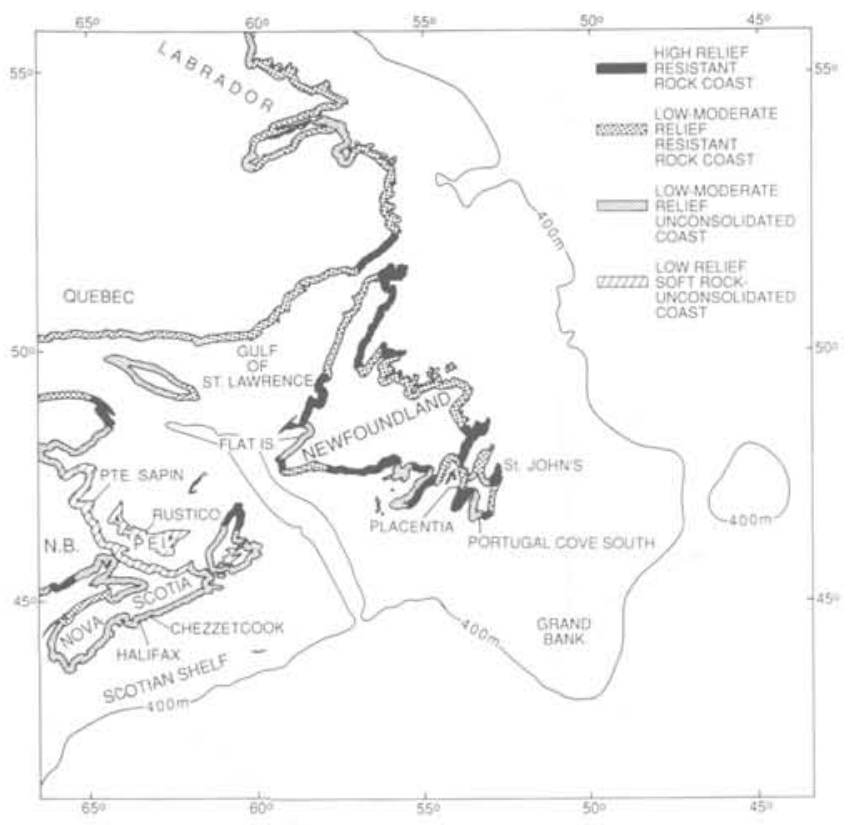

Figure 1: Generalized coastal types in eastern Canada and place names referred to in the text. in dramatic fashion the coastal erosion problem facing residents along parts of the north coast of Prince Edward Island and at many other locations in eastern Canada where the coast is formed in non-resistant rock or unconsolidated material (Fig. 1).

Canada does not, in general, have the level of investment in the shore zone that is found in areas such as the eastern United States, where centres like Atlantic City, New Jersey, and Ocean City, Maryland, have extensive high-rise developments within the shore-zone, and where major

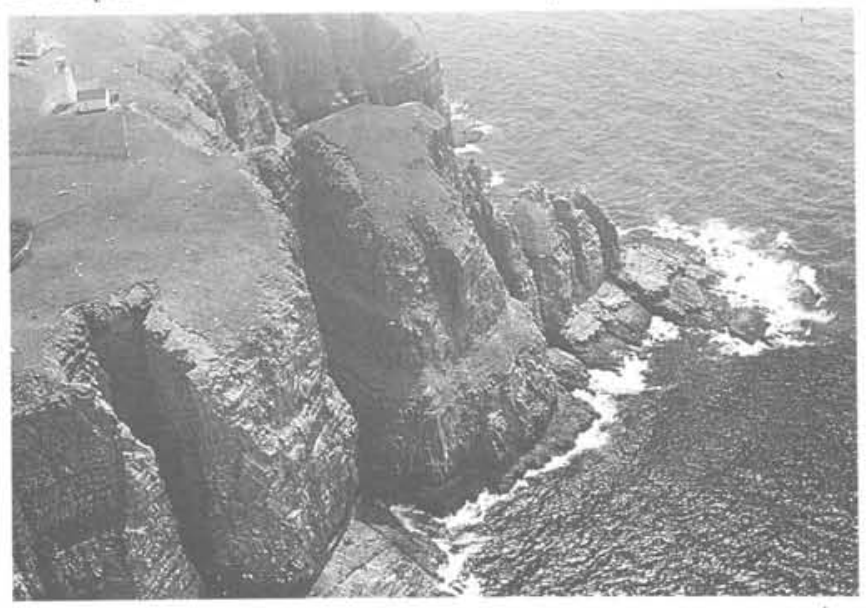

Figure 2: Lighthouse on 100-m high rock cliffs of Cape St. Mary's, south of Placentia, on the southern Avalon Peninsula of Newfoundland.

storms can wreak havoc in barrier island communities (Onysko and Kelsey, 1979; Leatherman, 1982). Whereas expensive protection works or beach replenishment may be an economically viable response to rising sea levels and associated coastal erosion at places such as Ocean City (Titus et al., 1985), this is often not the case where property values and population densities are lower. In addition, public perception of the erosion threat may vary (e.g. Rowntree, 1974; Ives and Furuseth, 1988), and construction continues today at many locations within zones of coastal flood or erosion hazard.

The coastal response to changes in wave energy, relative sea (or lake) level, or other environmental factors is strongly conditioned by the coastal geology and geomorphology and by sediment availability within the coastal system. While this may seem self-evident, it is helpful to remember that most models of coastal evolution have been developed for sand-dominated settings; in other situations they may not apply. For example, Kamphuis (1987) has shown that in areas where the material exposed at the coast contains less than $10 \%$ sand and gravel (a common situation along parts of the Great Lakes shorelines), cliff erosion processes differ significantly from those observed in sand-rich settings.

Yet another set of erosional processes will prevail along a coast formed in resistant rock (Fig. 2). Less obviously, perhaps, gravel-dominated coasts (even where sand is present in substantial quantities) show distinctive morphological features and patterns of shoreline development (Carter and Orford, 1984; Carter et al., 1987). This is particularly 


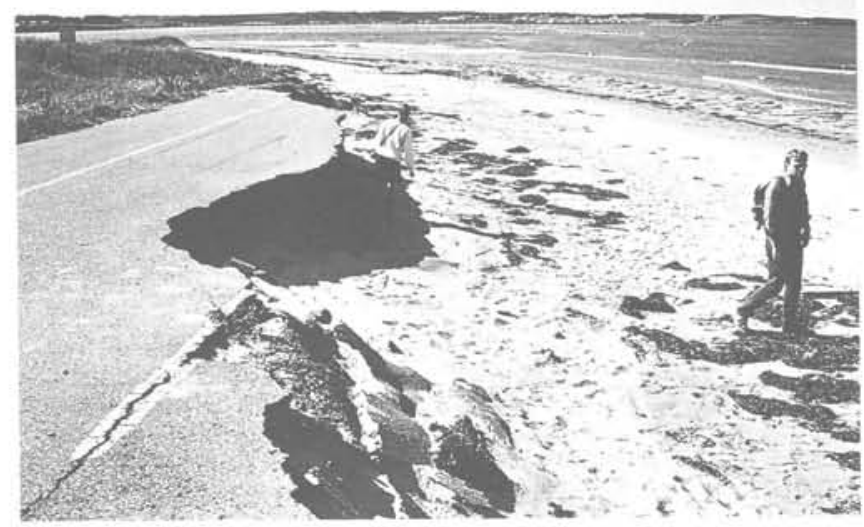

Figure 3: The road to Rustico: rapid widening of the tidal inlet at the mouth of Rustico Bay, on the central north coast of Prince Edward Island, has resulted in abandonment of this road.

important in formerly glaciated areas such as the Canadian Atlantic coast, where glacial deposits with widely varying clast sizes are the major sources of sediment for coastal development (Forbes and Taylor, 1987).

\section{Coastal Erosion in Eastern Canada}

At several locations along the Atlantic coast of Nova Scotia, parts of the coast have literally disappeared within living memory. Some residents of Lower East Chezzetcook recall taking hay off a field that lay on a low hill facing the sea, a site today occupied by a field of boulders, exposed only at low tide. The bridge that once led across a small tidal inlet onto the field is now buried in the beach (see discussion below and photograph of authors at the end of this article).

Taylor et al. (1985) have described changes in a barrier formerly known as Silver Sands Beach, at Cow Bay immediately east of Halifax. This once-popular bathing beach, which at one time was backed by a number of relict gravel beach ridges (McIntosh, 1916), is now reduced to a single gravel storm ridge with a very thin and localized wedge of foreshore sand. Commercial extraction of beach material in the 1950 s and 1960 s here radically altered the sediment budget, resulting in rapid barrier recession. Similar dramatic changes, some involving human intervention, have been documented in other parts of the Atlantic Provinces (e.g. Bowen et al., 1975; Reinson and Frobel, 1980; Taylor et al., 1985; Shaw and Forbes, 1987).

To learn more of the sea-level history and coastal response along the Nova Scotia coast, we have to go seaward onto the inner continental shelf. Figure 4 is an example of the stratigraphy observed in shallow seismic profiles collected over submerged valleys on the inner shelf. It shows an estuarine fill overlying glacial till and stratified outwash deposits at a site in $30 \mathrm{~m}$ water depth, approximately $5 \mathrm{~km}$ seaward of the former hayfield described earlier. The estuarine deposits are exposed locally on the sea floor in shallow depressions observed where the overlying veneer of sand is absent. A ${ }^{14} \mathrm{C}$ date of $7500 \pm 120$ years $\mathrm{BP}$ was obtained from saltmarsh peat near the base of a core that penetrated this deposit (Forbes et al., 1988). Geophysical profiling, geological sampling, palaeoecological analysis, and radiocarbon dating have enabled us to establish the history of relative sea level along this coast back to more than 9000 years before present, when the shoreline was roughly $40 \mathrm{~m}$ lower than it is today.

\section{Rising Sea Levels and Coastal Response}

Tide gauge records at Halifax extend back to the $1890 \mathrm{~s}$, longer than any others in the region. They indicate that relative sea level here has been rising at an unusually high rate of about $4 \mathrm{~mm} /$ year (equivalent to $40 \mathrm{~cm}$ per century) over the past 50 years (Grant, 1970). This represents an increase from the lower rate of $20-30 \mathrm{~cm}$ per century that prevailed in the early part of the tide gauge record and (on geological evidence) for the past 5000 years or so (Scott et al., 1987; Forbes et al., 1988).

Possible increases in global mean temperature over the next century, resulting from the greenhouse effect, may produce a substantial increase in the volume of water stored in the oceans, leading to very dramatic rates of sea-level rise (a range of published predictions is shown in Fig. 5). Although there remains considerable uncertainty both about the present trend of global mean sea level (e.g. Pirazzoli, 1988) and about the reliability of predicted increases over the coming decades, it is clear that consideration needs to be given to coastal response (e.g. Dean et al., 1987; Lane and Associates Limited, 1988).

What are the implications of anticipated sea-level rise for towns such as Placentia, in southern Newfoundland (Fig. 6), located on a 2000-year-old gravel beach-ridge plain (Shaw and Forbes, 1988)? Originally settled in the 16 th Century because of its suitability for drying codfish, Placentia has in

Figure 4: Interpreted section from shallow seismic record (CSS Dawson cruise 87042) showing estuarine deposits overlying outwash sediments and glacial till in a shallow submerged valley on the inner scotian Shelf, in approximately $30 \mathrm{~m}$ water depth. Sample of estuarine organic mud collected by diver from exposure on the sea floor gave a radiocarbon date of $6790 \pm 80$ years BP. Saltmarsh peat at the base of a nearby core was dated at $7500 \pm 120$ years BP, placing local relative sea level at that time close to $34 \mathrm{~m}$ below present. 


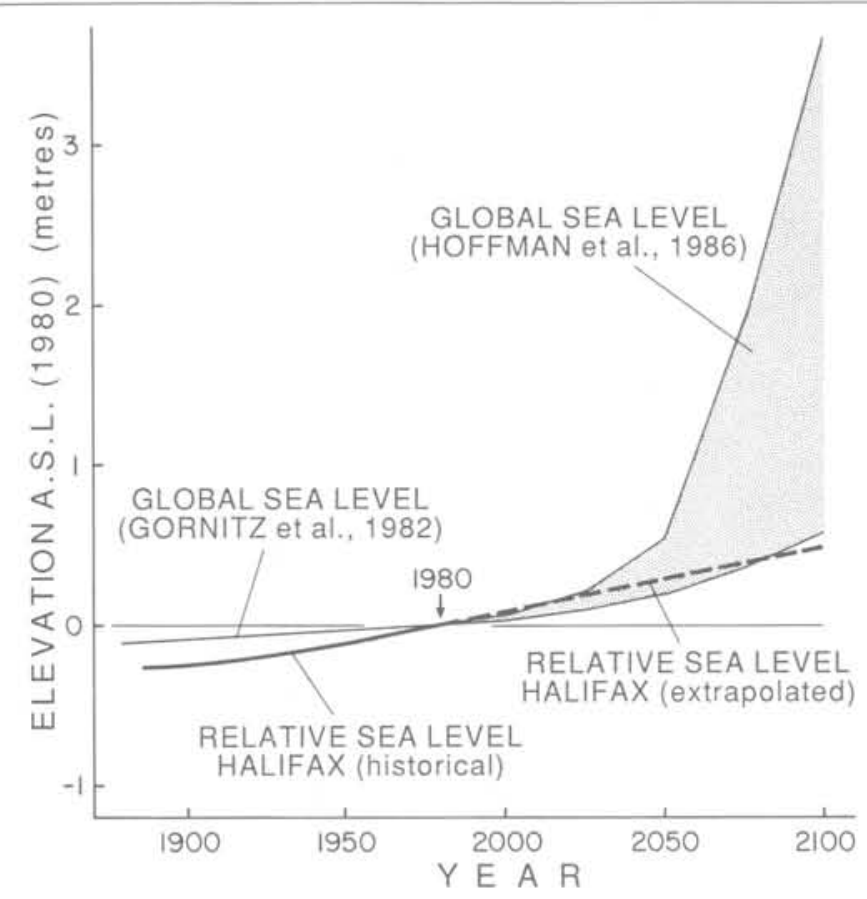

Figure 5: Global sea level history. After Gornitz and others (1982) and range of projected scenarios, after Hoffman and others (1986), with historical and extrapolated relative sea level at Halifax, Nova Scotia, for the years 1890 to $2100 \mathrm{AD}$.

very recent years seen considerable property development. In January 1989, as on a number of other occasions in recent years, storm-driven waves and high tides caused extensive flooding and property damage. How do we ensure that coastal communities are prepared for global sea-level rise, or indeed that we manage the coast effectively with the rates of sea-level rise occurring today?

An added complication over much of eastern Canada is ongoing residual subsidence from the collapse of a broad marginal forebulge caused by late-Wisconsinan glacial loading of the lithosphere to the north and northwest. Geodetic re-levelling suggests that at Halifax, for instance, this effect may account for $75 \%$ or more of the $40 \mathrm{~cm} /$ century sea-level rise seen in the tide-gauge records (Grant, 1970). Present evidence suggests that subsidence extends throughout the Maritime Provinces and Newfoundland (Forbes and Taylor, 1987). In simple terms, an increase in global sea level will be added to the relative rise in sea level due to land subsidence. One of the best ways to gauge this local effect is to study cores from salt marshes and other

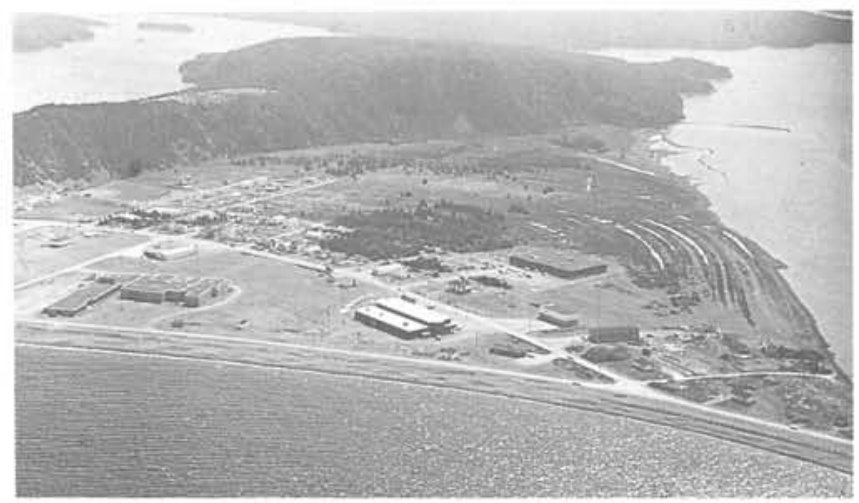

Figure 6: Western section of the beach-ridge plain, Placentia, Newfoundland. Oblique aerial view showing new shopping centres and high school.

coastal deposits that provide a geological record of local changes in relative sea level over the past few hundred to few thousand years (e.g. Honig, 1987; Scott et al., 1987; Shaw and Forbes, 1987).

Determining the rate of sea-level rise is only part of the problem, however. We need to know the coastal response in terms of shoreline recession and other effects as well. Bruun (1962) formulated a model to predict the coastal erosion caused by a given rise in mean sea level. Where there are no onshore or offshore exports or imports of sediment, no gradient in the longshore sediment transport potential, an erodible shoreline and sufficient cross-shore transport potential, Bruun hypothesized that the system would adjust to raise the equilibrium shoreface profile by erosion of an equivalent volume of sediment at the shoreline. This led to the result, which eame to be known as Bruun's Rule, that the shoreline recession, s, could be calculated as $s=a /[\tan B]$, where $a$ is the increase in relative sea level and $B$ the mean slope angle.

Unfortunately, Bruun's assumptions are satisfied only rarely, so that in most places prediction of the coastal recession is a much more difficult task. Furthermore, where sediment supply is abundant and longshore transport gradients exist, major coastal deposits may accumulate, even under conditions of rising sea level. Figure 7 shows a large spit complex, $12 \mathrm{~km}$ long, at Flat Island in southwest Newfoundland. This feature has developed over the past few thousand years, with relative sea level rising at a rate of about $1 \mathrm{~mm} /$ year (Shaw and Forbes, 1987), at the downdrift end of

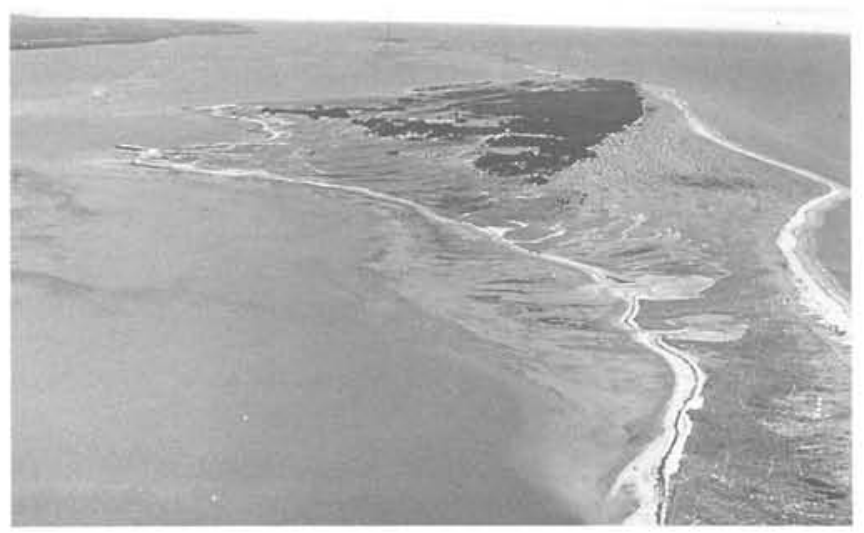

Figure 7: Oblique aerial view looking updrift (southwest), showing distal end of Flat Island barrier, St. George's Bay, southwest Newfoundland.

a $40-\mathrm{km}$ longshore transport corridor fed by eroding bluffs. The spit includes a narrow transgressive proximal (updrift) section, an early beach-ridge sequence near the updrift end, a breached central section through which sediment moves onshore, and a distal sink (Fig. 7, foreground) consisting of sand-capped gravel beach ridges resting on a sandy spit platform.

\section{Sediment Supply Limitations and Coastal Response}

Much of the Canadian Atlantic coast is formed in resistant rock and characterized by an extreme scarcity of mobile sediment (Figs. 1 and 2; Forbes, 1984). Where sediment is present, it is mostly of glacial origin and may be very coarse grained (Fig. 8), responding in ways quite different from those established for sandy shorelines (Carter and Orford, 1984).

In general, as time progresses following deglaciation, glacigenic deposits are reworked and the quantity of new material available to the coast declines, as suggested by the schematic model in Figure 9. The shaded area in the figure is based on ideas proposed by Church and Ryder (1972) to describe the postglacial decline in sediment yield from 
fluvial drainage basins in paraglacial settings. The solid line above (with various bumps and wiggles) is intended to represent a coastal analogue, with intermittent input of sediment from new sources (superimposed on a long-term decline in the sediment supply) as sea level rises across glaciated terrain.

Shaw and Forbes (1987) have documented the effects of such a decline in sediment supply in small bayhead barriers on the southern Avalon Peninsula, southeast Newfoundland. Figure 10 shows a close-up of the barrier at Portugal Cove South, where a series of low prograded beach ridges is fronted by a high gravel barrier moving back landward across the old beach-ridge complex. Although rising sea level may have played a part in the changes that have occurred here, the switch from regressive (seaward-building) to transgressive (landward-moving) behaviour in this beach system is believed to have been eaused by an inexorable decline in sediment supply. On the other hand, we are not yet at the point where we can readily predict when such changes in beach response will occur. They represent thresholds of stability in the coastal system, an issue that needs much more attention.

Similar kinds of changes can be seen along many parts of the Nova Scotia Atlantic coast, where glacial drumlin headlands form the major sources of sediment for beach development

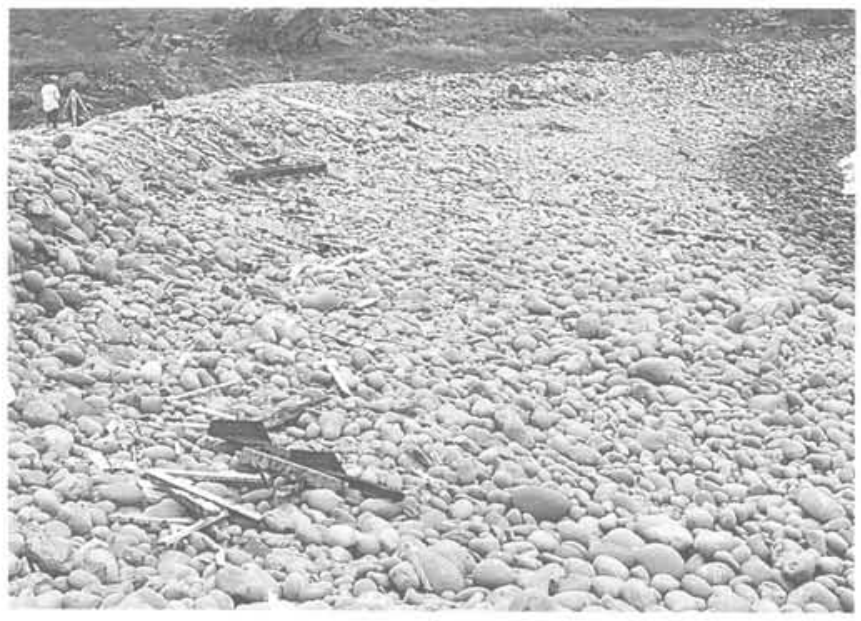

Figure 8: well-rounded cobbles and boulders forming small bayhead barrier in Freshwater Bay, just south of St. John's, Newfoundland.

(Sonnichsen, 1984; Piper et al., 1986; Boyd et al., 1987). As relative sea level rises, an erosional front progresses through the drumlin field, successively consuming the sediment content of individual drumlins (Fig. 9). Boulders in the drumlin-forming till are left behind as a lag shoal, while sand and gravel move alongshore into adjoining barriers (Carter et al., 1987), much of the sand ending up in back-barrier lagoons (Honig, 1987). With erosion rates ranging between 0.3 and $5 \mathrm{~m} /$ year (roughly) and an average drumlin axis length of about $1 \mathrm{~km}$, the consumption of individual drumlins and the life-times of the associated beaches extend from a few hundred years to between two and three thousand at most. The critical factor in this setting is, again, sediment supply, which at certain times in the cycle may be sufficient to cause beach progradation, despite the rapid rate of sea-level rise. Coastal evolution is largely controlled by the rate of supply from local sources within coastal cells that have longshore scales of a few kilometres or less.

One of the most dramatic examples we have observed is at Story Head (Fig. 11), a drumlin now almost completely consumed. This headland is the sole source of contemporary sediment supply to two adjoining barriers, the drift-aligned

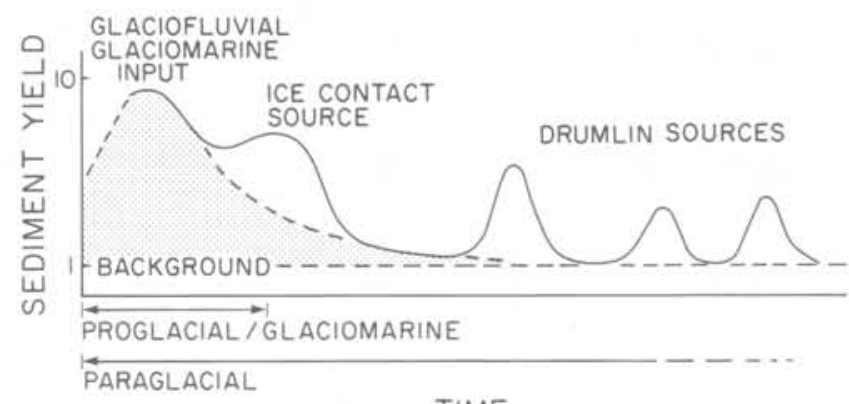

TIME

Figure 9: Schematic representation of paraglacial sediment yield in a transgressive coastal system. After Forbes and Taylor (1987).

trailing spit on the west and the now deeply embayed barrier on the east. This barrier was relatively stable from at least the time of a chart prepared by Cook (1766) until the time of the first air photos in 1945. At that time, it also derived sediment from a cliff fronting the old hayfield mentioned earlier. Sometime in 1954 (possibly as a result of Hurricane Edna), the barrier "took off," moving landward at an average rate of $8 \mathrm{~m} /$ year for the next 30 years. Recent surveys have shown continuing migration at a rate of about $5 \mathrm{~m} /$ year. Under these conditions, the integrity of the barrier can only be maintained if sufficient sediment is supplied along the trailing ridge linking the drumlin eliff source to the migrating barrier. The development of a breach at the distal end of the trailing ridge (Fig. 11) two years ago suggests that the supply may be failing.

The southern coast of the Gulf of St. Lawrence (Fig. 1) appears to be an area of abundant sediment supply, given the non-resistant sandstone and large barrier beaches characteristic of the region (McCann, 1979). Sedimentation is a serious problem at many harbours in the region, necessitating costly dredging operations (Fig. 12). However surveys of the inner shelf off the northeast coast of New Brunswick (Kranck, 1971; Forbes, 1982) and northern Prince Edward Island (Forbes, 1987) have demonstrated that mobile sediment is thin or absent over large areas.

Investigations at Pointe Sapin showed that much of the nearshore sea floor was occupied by a bare rock platform, and that the longshore drift was confined to a very narrow

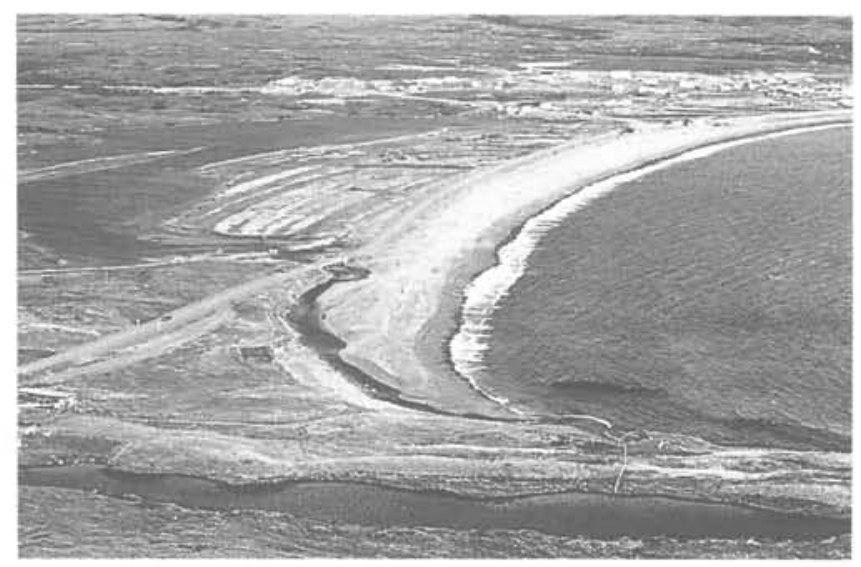

Figure 10: Oblique aerial view of barrier at Portugal Cove South, southeast Newfoundland, showing low, relict, beach ridges (representing an earlier phase of seaward progradation) over-ridden by high transgressive barrier (modern storm ridge). 


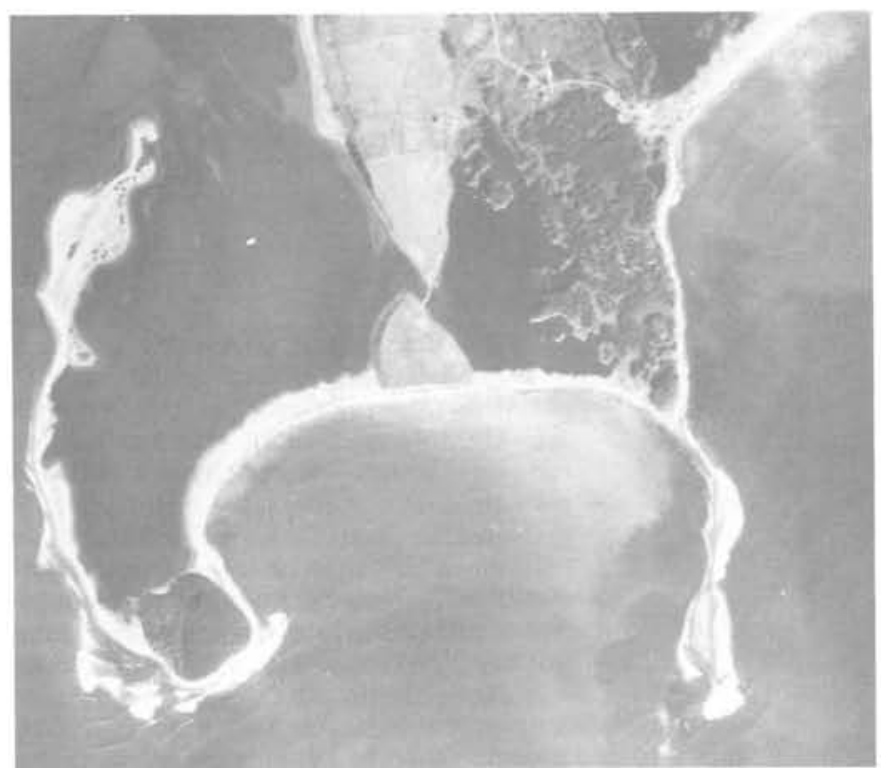

Figure 11: Vertical air photographs showing Story Head and associated barriers in 1960 (left) and 1974. Note former hill with hayfield and bridge (circled) now buried in the beach. For scale, length of barrier from distal end of trailing ridge

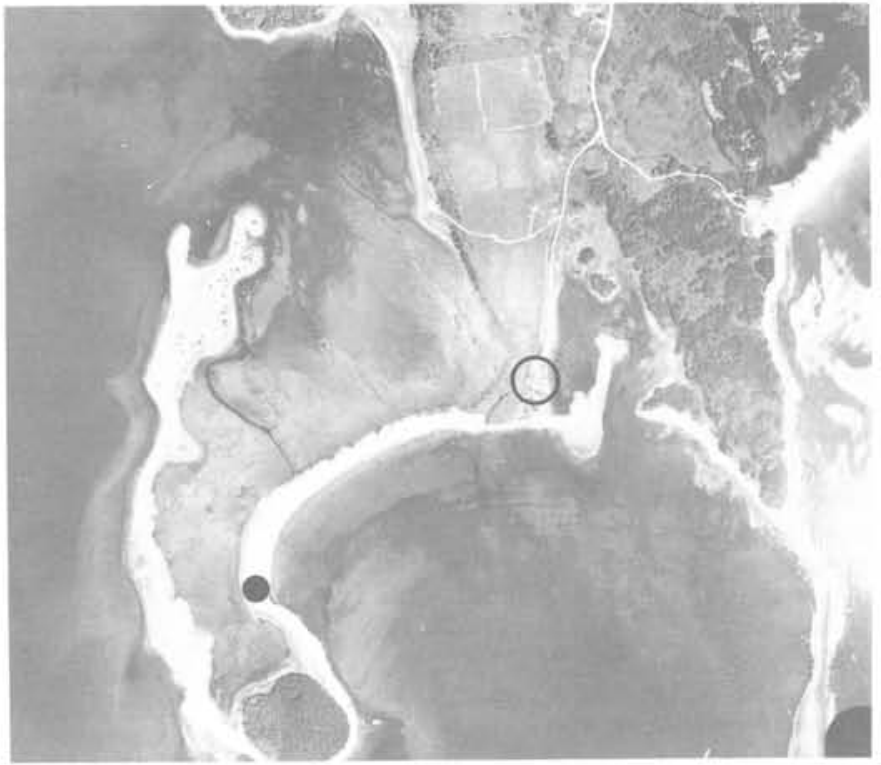

(large solid circle) to bridge (open circle) is approximately $800 \mathrm{~m}$. Airphotos Al7232-98 (National Air Photo Library, Ottawa, left) and 74122-190 (Land Registration and Information Services, Amherst, Nova Scotia). transport path along the shoreline. In 1980, an offshore breakwater was constructed to trap sand moving along the beach and thereby alleviate problems of sedimentation in the harbour entrance (Pratte and Willis, 1982). Surveys have shown, however, that in the area immediately updrift from the harbour a secondary transport path along the seaward margin of the rock platform (Forbes, 1982, 1987) allows some sand to bypass the sandtrap.

\section{The Implications}

These examples illustrate the complex nature of the coastal system and the need for a holistic approach to erosion and sedimentation problems there. Models of sediment transport and profile adjustment, as well as of coastal response

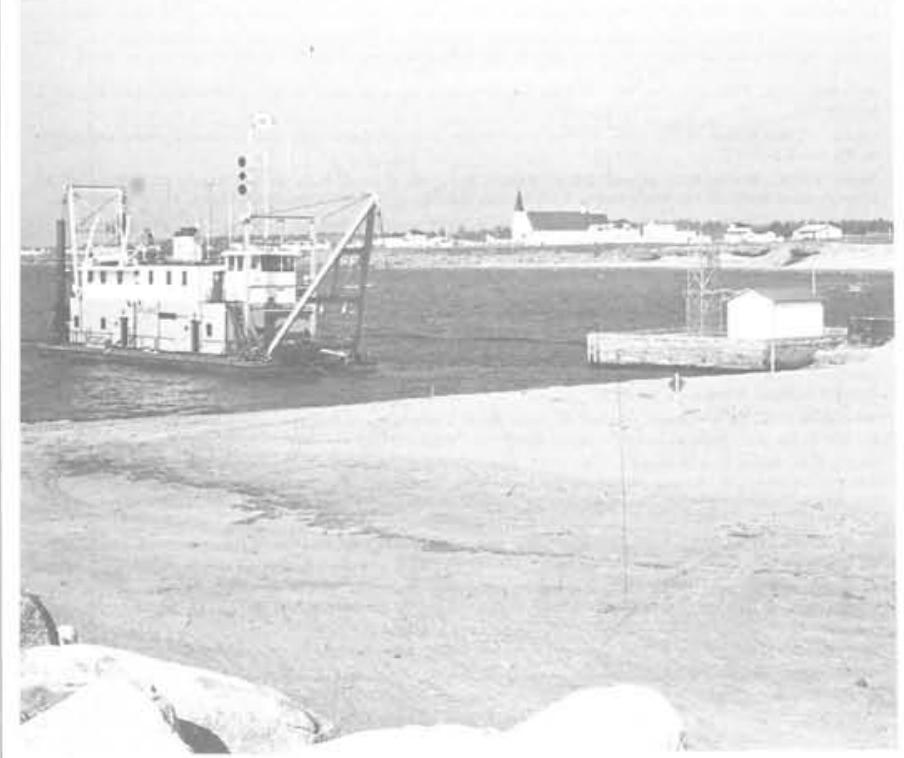

Figure 12: Dredge working to clear sandtrap between offshore breakwater (rubble in foreground) and mouth of harbour, Pointe Sapin, New Brunswick. to varying wave climate, sediment supply, and changes in mean water level can provide useful guidance and should be developed further. However, careful consideration of site conditions, sediment supply, and transport pathways are required for effective analysis of coastal problems prior to any engineering intervention in the littoral zone. The results obtained at Pointe Sapin and elsewhere have underlined the importance of processes operating on the inner shelf to an understanding of coastal stability. More work is also needed to understand the stability and evolution of gravel-dominated shores and their response to rising relative sea level. While our work at Story Head has provided clues to the complex behaviour of such systems, the situation of communities such as Placentia demonstrates that these issues have more than academic relevance.

A full appreciation of coastal processes may remain an elusive goal. Reliable predictions of mean sea levels and wave conditions 50 or 100 years hence may be some way off as well. Nevertheless, with a continuing effort to improve our understanding and with appropriate coastal management policies, we can be ready to face the as-yet uncertain consequences of global change, to manage coastal development effectively, to minimize damage and maintenance costs, and to preserve the aesthetic qualities that are an important part of our coastal heritage.

\section{Acknowledgements}

The ideas and examples presented here are culled from a wide range of field studies involving numerous fellow workers, all of whom we thank for their stimulating company and contributions. We also wish to acknowledge Art Cosgrove, Roger Bélanger, and their colleagues for drafting and photographic support, and Arnaud Héquette and Gary Sonnichsen for eritical reviews of the manuscript. This paper is published with the permission of the Geological Survey of Canada as GSC Contribution Number 52488 . 
Dr. D. L. Forbes is a Research Scientist with the Geological Survey of Canada (Atlantic Geoseience Centre, Box 1006, Dartmouth, N.S., Canada B2Y 4A2). His research interests have included coastal erosion and sedimentation processes, sediment dynamics and deposits on the inner shelf, and Holocene sea-level variability, with work in the Beaufort Sea area, Arctic Archipelago, Canadian Atlantic Provinces, and Ireland.
The authors ( $L-R$ : Forbes, Taylor, Shaw) on the remains of a bridge buried in the beach near Story Head, Nova Scotia.

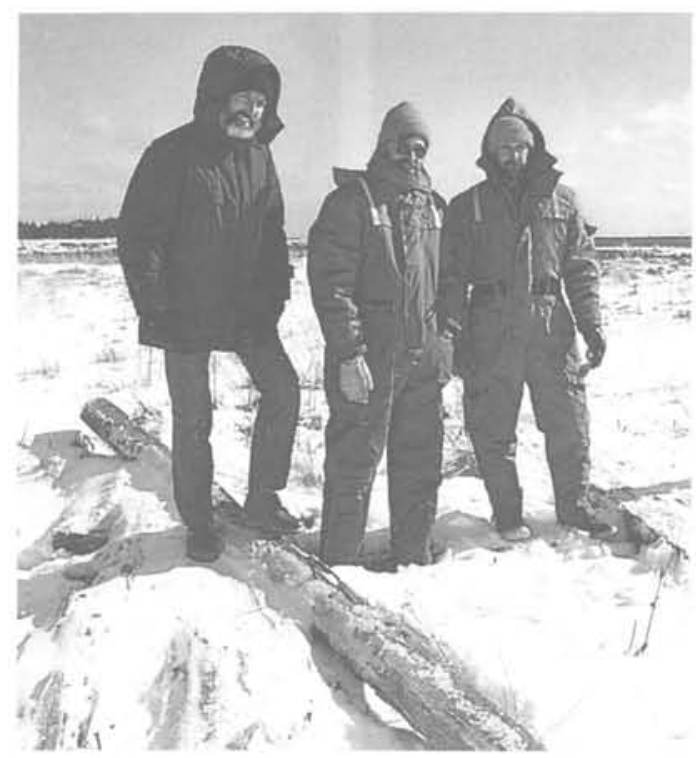

R. B. Taylor is also based at the Atlantic Geoscience Centre. He has worked on Arctic coastal processes, with emphasis on ice interaction processes at the shore, and on problems of coastal stability in eastern Canada. In recent years, he has been involved in studies of coastal erosion, beach stability, and coastal dune development in the Maritime Provinces and Ireland.
Dr. J. Shaw is a coastal geomorphologist and pollen specialist with the Coastal Group at the Atlantic Geoscience Centre. He has worked on beach morphodynamics and Holocene coastal evolution in Antrim and Donegal, Ireland, and more recently on coastal and shallow-marine sediments and Holocene sea levels from estuaries and salt marshes in Newfoundland and Nova Scotia.
References.

Bowen, A.J., (ed.), 1975, The minintenance of beaches. Technical report. Inatitute of Enviromental Studies, Dalhoniste University, Halifax, 583 .

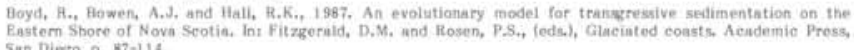

Bruun, P, 1962. Sea-tevel rise an n eause of shore eroston. Proceedings, Amerienn Soelety of Civil Engineers, Jourhal Waterways and Harbors Division, v. 84, Paper 3065, p. $117-130$.

Carter, R.W.G, and Orfort, J.D., 1984, Conrse elastic barrier beachest A discussion of the distinctive dynamir and morphosedimentary characteristics, Marine Geology, v. 60, no. 1-4, p. 377-389.

Carter, R.W.G., Orford, J.D., Forbes, D.L. and Taylor, K.B., 1987, Oravel barriers, hendiands and lagoonss un evolutionary modeL. Proceedings, Coestal Sediments '87 (New Orleans). Amerienn Society of Civil Engineers,

Church, M, and Ryder, J, M, 1972. Paragiacial sedimentations a consideration of nuvial processes conditioned by glaciation. Geologienl Society of Amerien, Bulletin, v. 83, no. 10, p. 3059-3072.

Cook, J., 1766. A draught of the Harbour of Hallifax and the adjacent eoast of Nova Scotia. Published by the nuthor nceording to Aet of Parliament, scale le77225. (Daihousie University, Halifax, William. Inglis Morse Dear, R.G., Dalrymple, R.A., Yairteridge, R.K., Leatherman, S.P., Numinedal, D., O'Brien, M.P., Pilkey, O.H., Stunces, w., III and wiegel, R.L. (Committee on Engineering Implications of Changes in Aeistive Sean Sea Wevelington, 1485.

Eyles, N., Eyles, C.H., Lau, K. and Clark, B., 1985. Applied sectimentology in an urban environment; the ease of Searborough
p. $91-104$.

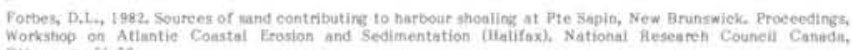
Workstiop on Atin
Ottawia, p. $51-58$.

Forbes, B.L., 1984. Coastal Be

Forbes, D.L., 1987. Shoreface sediment distribution and sand supply at $\mathrm{C}^{2} \mathrm{~s}^{2}$ sites in the southern Guit of St. Lawrence,

Forbes, D,L., Boyd, R., Staw, J., Jahaston, L., Hiefller, D.E., and MeL.aren, S., 1988. Cruise report 87042; CSS Dawson operations on the inher Seotian Shelf and Sabie lesand Aank. Geologienl Survey of Cannda Open File,

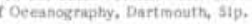

Forbes, D.L. and Taylor, H.B., 1987. Coarse-gruined beech sedimentation under paragiacial conditions, Caniondian Atiant
Diego, p. Si-86,

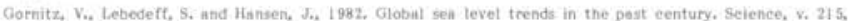
no. 4540, p. $1611-1614$.

Grant, B.18., 1970. Reeent coastal sutinergence of the Maritime Provinees, Canada. Canadiant dournal of Earth

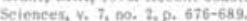

Hofrman, J.S., Welis, J.B. and Titus, J.G., 1986, Future global whrming and sen level rise. Proceedings, loeland Constal and Hiver Sympesium (Reykiavik), National Knengy Authority, Reykjaxik, P, 245-266.

Honis. C.A., 1987. Estuntine sedimentation on n ghacinted eoant, Lawrencetown Lake, Eastern Shore, Nova Geotia. Centre for Marine Geology, Daihousie thiversity, Halifax, Technical Report no, 9, 1 $132 \mathrm{p}$. tves, S. M. and Furaseth, O.J.. 1988. Community response to eosstal ensiont the view from two North Caralina
Kamphuis 2.W., 1987. Recession rate in glacial till bluffs Journal of Waterway, Port, Coastal and Oceat

Kranck, K., 1971. Surfieial geology of Northumberiand Strait. Geologieal Survey of Canada, Ottawa, Paper Lane, P, and Assoeiates Limited, 1988. Preliminary study of the possible impaets of a one metre rise in sea level at Chariottetown, Prince Edwaind trianc, Enver

Leatherman, 8.P., 1982. Barrier Lstand Handbook (2nd edition). University of Maryland, Collinge Park, 109. MeCann, S.B., 1979. Aarrier isinnds in the southern Gualf of St. Lawrence, Canada, In: Leatherman, S.P., (ed.),
Barrier lainads from the Gulf of St. Lawreoce to the Gulf of Mexico. Academic Press, New York, p. 29-63. Melintoshs

Onysko, S. and Kelsey, R.C., 1979. Barrier beach storm darninges Cape Cod, Massachusetts Shore and Beach. p. \#-11.

Piper, D.J.W., Mudte, P.J., Letson, J.R.J., Harnes, N.E. and lutiucel, H.J., 1985, The mannine geology of the Pirazzoli, P.A., 1988, Sea-level correlationat applying 10CP results Episodes, k. 11, no. 2, p. 111-116.

Pratte, B.D. and Willis, D.H., 1982. Pointe Sapin harbodr - offshore breakwater and sandtrap. Proceedings, Workshop on Atlantic Coastal Erosion und Sedimentation (Halifax). National Researeh Council Canada

Readahnw, J.S., 1987. Heview of man-made changes to Traeadie, Shippigan, and Rustico Inlets. Proceedings, Canadian Coastal Co

Reinson, G.E. and Frobel, D., 1980. Effoets of dredging activities on shoreline morphology and stablity, northeast New Brunswick, Proceedings, Canadian Coastai Conference 1980 (Burlington). Natianal Reseasc Rowntree, H.A., 1974. Coustal erosion: the meaning of a natural hazard in the eulturat and ecological context.

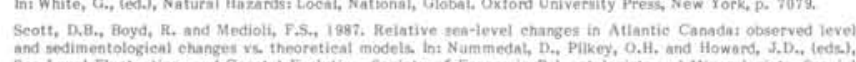

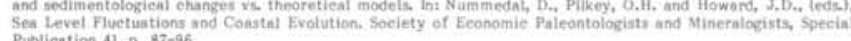

Shaw, J. and Forbes, D.1., 1987. Coastal barrier and beach-rioge sedimentation in Newfoundland. Proceetings

Shaw, J. and Forbes, D.L., 1988. Crustat warping and sediment supply as controls on recent constai Sonnichsen, G., 1984, The relationstip of coastal drumlins to barrier beach formation alorg the Eastern Shore Centre for Marine Geology, Dalhousie University, Halifax, Technical Report no, $5.68 \%$ Taylor, I.B., Wittmann, S.L., Miline, M.J. and Kobar, S.M., 1983. Heach mophoiogy and coastal ehanges at

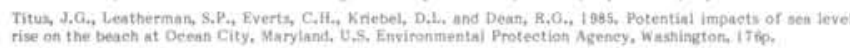

